\title{
PROFITABILITY ANALYSIS OF PUBLIC-PRIVATE PARTNERSHIP IN HEALTHCARE DELIVERY IN SPAIN
}

\author{
Silvia González-de Julián ${ }^{1}$, Fernando Polo-Garrido ${ }^{2}$, Isabel Barrachina-Martinez ${ }^{3}$, \\ David Vivas-Consuelo ${ }^{4}$ \\ ${ }^{1,2}$ Department of Economy and Social Sciences, Faculty of Business Administration, \\ Universitat Politècnica de València, Bulding 7j, Camino de Vera s/n, 46022 Valencia Spain \\ ${ }^{3,4}$ Center of Economic Engineering, Faculty of Business Administration, \\ Universitat Politècnica de València, Bulding 7j, Camino de Vera s/n, 46022 Valencia Spain \\ E-mails: ${ }^{1}$ silgonde@upv.es; ${ }^{2}$ fpolo@cegea.upv.es;

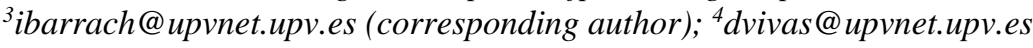

\begin{abstract}
In the Valencian Community (Spain) there are 5 health districts managed by public-private partnerships. They are the so-called Alzira model, where the concessionaire builds and maintains the hospital facilities and provides health care services. The purpose of this paper is to address problems raised in the calculation of the limiting clause of profitability and to develop a financial statement analysis in order to assess profitability, solvency and liquidity. Results indicate that all concessionaires show very high debt-to-assets ratio, low liquidity, ROA fluctuates between $2.45 \%$ and $12.42 \%$, and the IRR varies between $3.47 \%$ and $13.15 \%$. Despite this, four of five concessionaries exceed the limiting clause using an "ad hoc" method as proxy of "cash flows".
\end{abstract}

Keywords: Public Private Partnership, financial statement analysis, health care management.

JEL Classification: G00, H83, H75, I15.

\section{Introduction}

In 1999 the new modality of public-private partnership (PPP) was adopted in Spain, firstly in the health district of La Ribera in the Valencian Community, known as the "Alzira model".

This region has a population of about 4.7 million inhabitants and its health care system is constituted by 24 public health districts. Each health district has a reference hospital and several primary healthcare centers.

After this first PPP contract, other health districts were incorporated into the new PPP management system: Torrevieja (2006), Denia (2009), L'Horta - Manises (2009) and Elche Crevillente (2010). In total, 5 health districts, covering $20 \%$ of the Valencian Community population, have been established (Figure 1).

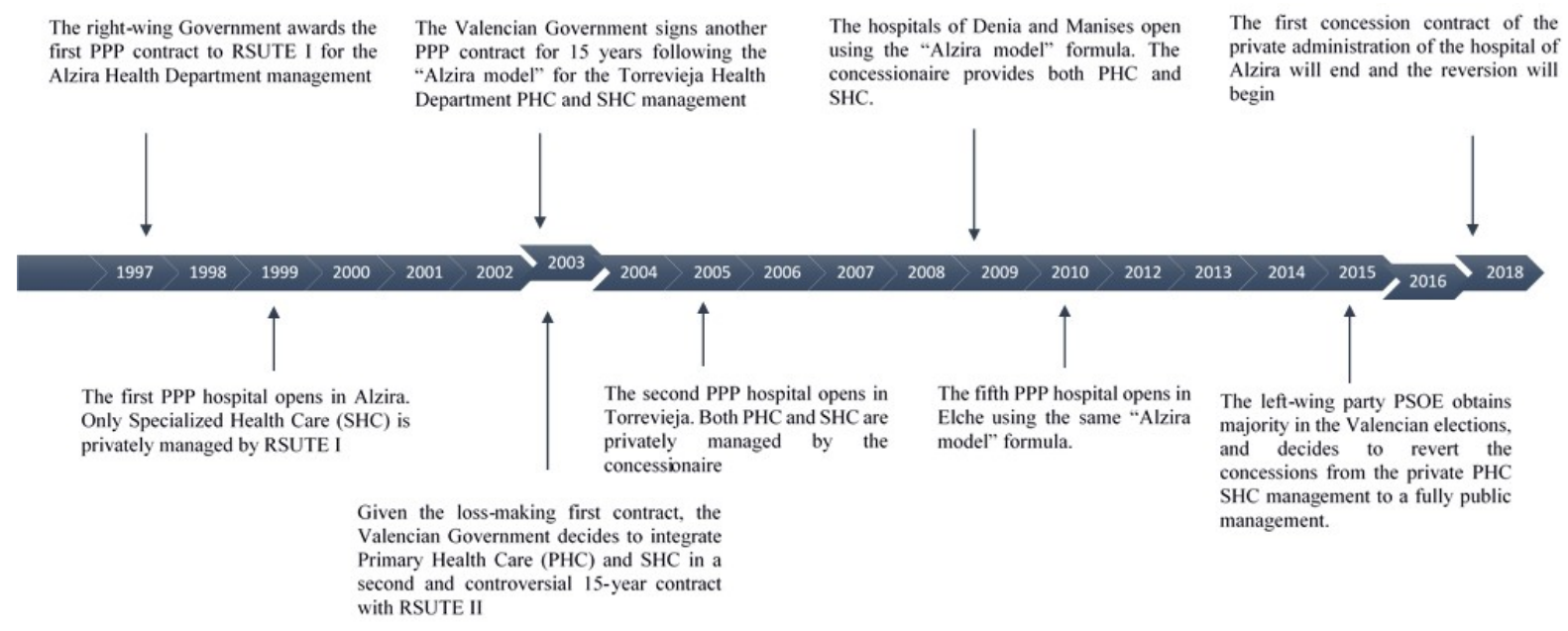

Figure 1. Timeline (source: prepared by authors)

(C) 2018 The Authors. Published by VGTU Press. This is an open-access article distributed under the terms of the Creative Commons Attribution License (CC-BY 4.0), which permits unrestricted use, distribution, and reproduction in any medium, provided the original author and source are credited. 
The contracts are granted for 15 years, extendable by mutual agreement for a further five years, and define the investments that the concessionaire is committed to.

The contracts include a clause to limit the profitability of the concessionaire. This limit is established as a maximum Internal Rate of Return (IRR) of $7.5 \%$. The limiting clause stipulates the calculation method taking as returns the accounting profit adjusted by amortization and the incentive for pharmacy savings on the investments made according to the contracts. The calculation of the IRR limitation has become extremely difficult in practice because of changes in accounting standards and mainly due to the resulting loss of needed information in the financial statements.

Since this system was adopted in the health district of Alzira in 1999 until now, the General Accounting Plan has experienced two important modifications that affect the accountancy applied by the concessions. The first in 2007, when the New General Accounting Plan, applicable to all kind of firms, was implemented (RD 1514/2007), and the most important, the second in 2010 with the establishment of the new accounting standards for concessional contracts (Order EHA/3362/ 2010). These changes were introduced because the government considered that the existing accounting methods were insufficient to correctly register the economic reality of the concessions and the new regulations aimed to establish a different treatment in the accounting of the facilities subject to the concession, as well as in the way that incomes and costs are estimated.

Regarding the infrastructure, the fact that it is the Public Administration that determines its physical use, the main characteristics of the service that should be provided, the potential client and price, and that the concessionaire does not bear the demand risk, leads the concessionaire company to register the facilities as a financial asset. The concessionaire receives the usage rights of the facilities and it manages the right to exploit the service and be paid for that.

The other main difference that the new accounting standards for concessional contracts introduces is how the incomes and the costs are calculated according to some estimates that are established in the economic-financial plan of the concessionaire, and their distribution throughout the years (life/duration) of the concession.

During the time the different concessions have been in operation, the covered population has been changing. This information is shown in Table 1, as well as the investments carried out to the start up of the activity.

It must be mentioned that Manises experienced a marked increase in its covered population in 2010. This was due to a readjustment to compensate for some economic issues caused by the reluctance of patients to change from their previously assigned hospital (Hospital Universitario $\mathrm{La} \mathrm{Fe}$ ), which belongs to another health district and is the hospital of reference for the Valencian Community.

The premium per capita has been changing as well, from 379 euros in 2003 until 737.19 euros in 2015.

Table 1. Basic data of the concessions (source: compiled by authors (2018))

\begin{tabular}{|l|c|c|c|}
\hline & $\begin{array}{c}\text { \% of } \\
\text { concession } \\
\text { life expired }\end{array}$ & $\begin{array}{c}\text { Investment } \\
\text { thousands } \\
\text { of euros) }\end{array}$ & $\begin{array}{c}\text { Average } \\
\text { population } \\
\text { (thousands) } \\
*\end{array}$ \\
\hline Alzira & $85.06 \%$ & 72,000 & $\begin{array}{c}247.4 \\
{[232.7-} \\
248.9]\end{array}$ \\
\hline Torrevieja & $61.42 \%$ & 82,364 & $\begin{array}{c}163.1 \\
{[150.0-} \\
157.9]\end{array}$ \\
\hline Denia & $46.10 \%$ & 90,929 & $\begin{array}{c}154.9 \\
{[157.1-} \\
151.7]\end{array}$ \\
\hline Manises & $44.37 \%$ & 94,375 & $\begin{array}{c}172.6 \\
{[148.1-} \\
194.3]\end{array}$ \\
\hline Elche - & $37.24 \%$ & 98,121 & $\begin{array}{c}143.3 \\
{[135.1-} \\
\text { Crevillente }\end{array}$ \\
& & & $148.9]$ \\
\hline
\end{tabular}

*Average population: the initial population covered and the population covered in 2015 are shown in brackets

In 2015, the political situation changed and the arrival in power of a left-wing government was accompanied by an interest in progressively reverting the concessions, which meant a return to a model where the public sector and private sector operate separately regarding health care.

The objective of this study is to analyse the results obtained by the different health districts managed by PPP in the Valencian Community and compare them using the available financial information. In addition, profitability was examined, given that this is limited in the terms of the contract to $7.5 \%$. 


\section{Background and previous research}

PPP can be defined as 'a long-term contract between a private company and a government agency, for providing a public asset or service, in which the private party bears significant risk and management responsibility' (World Bank Institute, 2012, p. 230; Vecchi, Hellowell, \& Longo, 2010, pp. 125-132).

In practice, there are different models that involve diverse forms of risk management, incentive, financing and payment of structures (Caballer-Tarazona \& Vivas-Consuelo, 2016, p. 17).

The UK is the country leader in PPP, having introduced the model in 1992 (Hellowell \& Pollock, 2009, pp. 13-19) and which is globally known as the Private-Finance Initiative (PFI). This model follows an infrastructural approach; this means that the concessionaire builds and maintains the hospital facilities, producing a risk transfer in the maintenance of the installations from the government to the concessionaire (Wang, Xiong, Wu, \& Zhu, 2017, pp. 1-24).

The Alzira model differs from the UK model in that the private company also delivers health care services. In this case, the responsibility assumed by the concessionaire is greater than in the UK model. The public financing is realized through a capitation fee.

Other PPP models have been established around the world, depending on the political preferences of the country and the characteristics of its national health care (Allard \& Trabant, 2007).

Some authors (Anderson, 2012, pp. 313-322; Hamilton, Kachkynbaeva, \& Wachsmuth, 2012, pp. 1-48; Singh \& Prakash, 2010, pp. 829-856) have presented a list of the PPP models implemented in different countries, for example the PPP based on lean contracts of the Philippines, the PPP facility-based hospitals in India or the infrastructural PPPs of the UK and Australia. These models generally vary in terms of the degree of private involvement. At one extreme we find the public provision, where the public sector is completely responsible for all aspects of delivering public services; while at the other extreme is the private provision, where the private company assumes all these responsibilities. As the PPP moves from one extreme to the other, the degree of private involvement increases. These PPPs also present differences in terms of finance sources and ownership of properties (Kwak,
Chih, \&Ibbs, 2009, pp. 51-78; Roehrich, Lewis, \& George, 2014, pp. 110-119).

These models, which were initially implemented to improve efficiency, the quality of medical attention and the satisfaction of the patients, have since been questioned regarding the benefits they provide to the society, with both supporters and detractors (Megha \& Panneer, 2017, pp. 17-24; Torchia \& Calabrò, 2015, pp. 37-41; Hoppe, Kusterer, \& Schmitz, 2013, pp. 145-166; Mudyarabikwa, Tobi, \& Regmi, 2017, pp. 366-375).

Compared to all the health districts in the Valencian Community, the PPP departments achieve generally good results, but not always better than those districts directly managed. The results, however, were not clearly conclusive regarding which was the better system (CaballerTarazona \& Vivas-Consuelo (2016, p. 17).

In addition, other authors state the importance of developing external indicators to allow the government that finances the health care activity to control and monitor the results of the concession and the quality of the services they provide (Jamali, 2004, pp. 414-430).

\section{Methodology}

\subsection{Data}

The main sources of information were the National and Regional Acts regarding the regulatory environment, the financial statements of the concessionaires, obtained from the Mercantile Registry and, finally, contractual documents were collected from the Transparency Portal of the Valencian Community (TPVC) and the System of Economic Information of the Regional Health Department (SEIRHD).

Additionally, we have the information from the definitive and provisional annual financial settlements with the Regional Health Authority of Valencia, as well as the files on unjust enrichment that took place during the period analysed.

The Regional Health Authority of Valencia annually allocates a quantity to each district managed by PPP, which is given by the addition/subtraction of the following amounts:

- $(+)$ A premium and fixed capitated payment;

- (+/-) The amount of the inter-center movement billing (patients referred to other health districts and patients received from other health districts); 
- (-) The amount for the procedures carried out in publicly managed health care centers (i.e. provided by fully public hospitals and used by patients that are part of a PPP Health Department);

- (+) An incentive for pharmacy savings (if the pharmaceutical spending per person in a Health Districts is less than the Valencian Community average, 30 per cent of the difference is included in the amount as an incentive);

- (-) Salaries of civil servants that work for the concession.

The fixed payment, which is the main component of these financial settlements, results from multiplying the premium per capita by the number of inhabitants included in the 'covered population', with a minimum increase determined by the annual variation in the Consumer Price Index. The premium per capita is exactly the same for each department, but varies each year. Therefore, the difference in the size of the population covered by the PPP Health Districts makes the fixed capitated payment different across territories. This premium per capita is paid to the concessionaire on a monthly basis.

Some of the concessionaires have received restitution when it was considered that the Administration had received an unjust benefit. Unjust enrichment occurs when one person is enriched at the expense of another in circumstances that the law sees as unjust and requires restitution of the benefit.

Regardless of the year that the different concessions started their activity, the analysis and comparisons between the concessionaires are focused on the period 2011-2015, when the new accounting methodology was implemented. However, the average ratios are calculated for the whole term of the contract, until the year 2015.

\subsection{Financial statements analysis}

We developed a financial statement analysis in order to assess profitability, solvency and liquidity. Financial statement analysis is one of the most used techniques in order to interpret and assess financial statements and to make decisions (Lev, 1974). The use of financial ratios is extensive (Lev \& Sunder, 1979, pp. 187-210) and are used for all kind of purposes (Barnes, 1987, pp. 449-461). Whittington identified two principal uses of financial ratios, the traditional, normative use of a firm's ratio compared with a standard, and the positive use in estimating empirical relationships, usually for predictive purposes (Whittington, 1980, pp. 219-232).

We assess profitability by means of the following ratios:

$$
\begin{aligned}
& \begin{array}{l}
\text { Return on assets ratio } \\
\text { (ROA) }
\end{array} \\
& \begin{array}{l}
\text { Return on Equity } \\
\text { (ROE) }
\end{array}
\end{aligned}
$$

Solvency is assessed by using the Debt-toassets ratio (DTA)

$$
=\frac{\text { Total Debt }}{\text { Total Assets }} \text {. }
$$

And liquidity is assessed by means of the current ratio

$$
=\frac{\text { Current Assets }}{\text { Current Liabilities }} \text {. }
$$

Finally, the internal rate of return (IRR) is determined, as the contract specifications include a clause to limit the profitability of the project for the concessionaire. The maximum IRR is established at $7.5 \%$, meaning any return exceeding $7.5 \%$ will go to the government.

The IRR is the interest rate at which the net present value (NPV) of all the cash flows (both positive and negative) from a project or investment equal to zero. Equivalently, it is the discount rate at which the NPV of future cash flows is equal to the initial investment.

$$
N P V=\sum_{t=1}^{T} \frac{C_{t}}{(1+r)^{2}}-C_{0},
$$

where: $C_{t}=$ net cash flow during the period $\mathrm{t} ; C_{0}=$ total initial investment costs; $r=$ discount rate, and $t=$ number of time periods.

So the formula for IRR is:

$$
0=C_{0}+\frac{C_{1}}{(1+I R R)}+\frac{C_{2}}{(1+I R R)^{2}}+\ldots+\frac{C_{t}}{(1+I R R)^{t}} .
$$

The IRR is used to evaluate the attractiveness of a project or investment. If the IRR of a new project exceeds a company's required rate of return, that project is desirable. If it falls below the required rate of return, the project should be rejected.

In order to calculate the IRR three different methods were used to estimate the annual cash flows.

Method 1.a: is performed according to what it is established in the contract, the schedule of 
specific administrative clauses and the Resolution of the Department of Health and Health Care Services of the Government of Valencia on $17^{\text {th }}$ October 2005, which clarifies that the annual cash flows should be calculated taking the result after taxes adjusted by amortization and the incentive for pharmacy savings.

Method 1.b: on the basis of the method 1.a, we add the interests paid to the shareholders due to the participation loan, as these should be considered a distribution of profits. However, as they are recognized as financial cost in the financial statements, they reduce the profitability of the concessionaire.

Method 2: a rough estimation of 'real' cash flows.

The changes in the accounting methodology and the use of estimates make the calculation of the IRR difficult.

Method 2 offers a different version to that presented by method 1 , with the aim of reflecting the reality of the business more accurately. It tries to estimate the profitability considering the real moment when collections and payments occur.

As collections we include:

- The premium per capita that is paid on a monthly basis and is the main collection that the concessionaire receives.

- The collections of the rest of incomes that appear in the profit and loss account are assumed to have taken place at the end of the year, as we do not have the necessary information to know the exact moment they occur.

And as payments:

- We assume that the costs, apart from valuation allowances ${ }^{1}$, that appear in the profit and loss account take place at the end the year.

- Adjustments introduced in the calculation model:

- Salaries of civil servants that work for the concession. The concessionaire records them as a cost of the year, but the real payment occurs when the annual financial settlement is liquidated, which is clearly deferred over time.

- Other results included in the annual financial settlements, such as the inter-center movements billing.
This collection or payment is included when it takes place.

Investments: the data was obtained from the records of the concessionaire. The investments are the same for all the methods.

It must be mentioned that when estimating the annual cash flows, as well as the incomes that are regulated by the contract, we include other incomes that the concessionaires obtain and that are considered non-contractual. It is assumed that the concessionaires are using the infrastructure and facilities of the hospital and that these noncontractual services could not be provided without them.

When calculating the IRR we also take into account the fact that the concession contract will finish after 15 years and will not be renewed.

\section{Results}

The concessions of Torrevieja and Manises present the best liquidity ratio, being above the average, while Alzira shows the greatest liquidity stress (Table 2).

Table 2. Liquidity ratio (source: compiled by authors from the financial statements (2018))

\begin{tabular}{|l|c|c|c|c|c|c|}
\hline & 2011 & 2012 & 2013 & 2014 & 2015 & Average \\
\hline Alzira & 1.06 & 1.13 & 1.24 & 1.09 & 0.88 & 0.89 \\
\hline $\begin{array}{l}\text { Torre- } \\
\text { vieja }\end{array}$ & 1.33 & 1.19 & 1.12 & 1.2 & 1.43 & 1.14 \\
\hline Denia & 1.02 & 1.14 & 1.11 & 1.22 & 0.99 & 0.98 \\
\hline $\begin{array}{l}\text { Mani- } \\
\text { ses }\end{array}$ & 1.1 & 1.5 & 1.65 & 1.71 & 1.68 & 1.35 \\
\hline $\begin{array}{l}\text { Elche- } \\
\text { Crevil- } \\
\text { lente }\end{array}$ & 1.28 & 1.3 & 1.28 & 1.09 & 1.02 & 1.02 \\
\hline
\end{tabular}

The capital structure indicates a high level of indebtedness, above $89 \%$ on average (Table 3 ). The best ratio is always obtained by the Alzira concession.

The ROA of the concessions, on average, shows a decreasing trend, almost disappearing in $2015^{2}$ (Table 4). The concessions of Torrevieja and Elche - Crevillente always maintain a positive ROA, although the last one shows a negative trend. The concession of Torrevieja

\footnotetext{
${ }^{1}$ That is to say amortisation and depreciation, impairment losses, gains or losses due to fair value measurement and changes in provisions.
} 
obtains the best ROA, with an average of $5.2 \%$, while the average of all the concessions is $2.5 \%$.

Table 3. Debt-to-assets ratio (source: compiled by authors from the financial statements)

\begin{tabular}{|l|c|c|c|c|c|c|}
\hline & 2011 & 2012 & 2013 & 2014 & 2015 & $\begin{array}{c}\text { Ave- } \\
\text { rage }\end{array}$ \\
\hline Alzira & $83 \%$ & $81 \%$ & $75 \%$ & $77 \%$ & $84 \%$ & $79 \%$ \\
\hline $\begin{array}{l}\text { Torre- } \\
\text { vieja }\end{array}$ & $91 \%$ & $95 \%$ & $96 \%$ & $93 \%$ & $83 \%$ & $92 \%$ \\
\hline Denia & $95 \%$ & $92 \%$ & $93 \%$ & $90 \%$ & $91 \%$ & $93 \%$ \\
\hline $\begin{array}{l}\text { Mani- } \\
\text { ses }\end{array}$ & $99 \%$ & $94 \%$ & $88 \%$ & $85 \%$ & $93 \%$ & $95 \%$ \\
\hline $\begin{array}{l}\text { Elche- } \\
\text { Crevil- } \\
\text { lente }\end{array}$ & $94 \%$ & $93 \%$ & $94 \%$ & $95 \%$ & $95 \%$ & $95 \%$ \\
\hline
\end{tabular}

Table 4. ROA (source: compiled by authors from the financial statements (2018))

\begin{tabular}{|l|c|c|c|c|c|c|}
\hline & 2011 & 2012 & 2013 & 2014 & 2015 & $\begin{array}{c}\text { Ave- } \\
\text { rage }\end{array}$ \\
\hline $\begin{array}{l}\text { Alzi- } \\
\text { ra }\end{array}$ & $0.6 \%$ & $0.6 \%$ & $1.4 \%$ & $0.8 \%$ & $-3.1 \%$ & $1.1 \%$ \\
\hline $\begin{array}{l}\text { Torre } \\
\text { vieja }\end{array}$ & $7.6 \%$ & $3.2 \%$ & $2.9 \%$ & $5.6 \%$ & $13.1 \%$ & $5.2 \%$ \\
\hline $\begin{array}{l}\text { De- } \\
\text { nia }\end{array}$ & $7.9 \%$ & $7.3 \%$ & $0.5 \%$ & $5.3 \%$ & $-2.4 \%$ & $1.5 \%$ \\
\hline $\begin{array}{l}\text { Mani } \\
\text { ses }\end{array}$ & $11.5 \%$ & $10.8 \%$ & $10.5 \%$ & $8.3 \%$ & $-10.4 \%$ & $2.5 \%$ \\
\hline $\begin{array}{l}\text { El- } \\
\text { che- } \\
\text { Cre- } \\
\text { vil- } \\
\text { lente }\end{array}$ & $5.0 \%$ & $5.2 \%$ & $4.5 \%$ & $2.9 \%$ & $3.2 \%$ & $2.3 \%$ \\
\hline
\end{tabular}

With regard to the ROE, great variability between concessions is observed (Table 5). Torrevieja shows the best results, as the ROE is always positive with an average of $12.3 \%$. Alzira achieves a positive average, although the ROE in 2015 was negative. Manises starts with a ROE of $805.7 \%$ in 2011 due in part to its high indebtedness (99\%), becoming negative in 2015 $(-121.5 \%)$, as this was the year the concession updated the hypotheses used to draw up its economic- financial plan, considering a more pessimistic scenario and this is reflected in the net result obtained that year.
Table 5. ROE (source: compiled by authors from the financial statements (2018))

\begin{tabular}{|c|c|c|c|c|c|c|}
\hline & 2011 & 2012 & 2013 & 2014 & 2015 & $\begin{array}{l}\text { Ave- } \\
\text { rage }\end{array}$ \\
\hline$\frac{\stackrel{\sqrt[T]{3}}{N}}{\frac{Z}{4}}$ & $\frac{\stackrel{\rho}{r}}{\dot{m}}$ & लें & î̀ & $\begin{array}{l}\text { ळे } \\
\text { mे }\end{array}$ & $\frac{b_{0}^{0}}{i}$ & $\stackrel{\stackrel{2}{\circ}}{\dot{m}}$ \\
\hline $\begin{array}{l}\cdot \frac{\pi}{0} \\
\frac{0}{2} \\
\stackrel{0}{0} \\
\stackrel{0}{0}\end{array}$ & $\begin{array}{l}\stackrel{\circ}{+} \\
\stackrel{+}{+}\end{array}$ & $\stackrel{\stackrel{े}{~}}{\sim}$ & ஸें & $\begin{array}{l}\stackrel{0}{2} \\
\dot{q}\end{array}$ & $\begin{array}{l}\delta^{0} \\
\infty \\
i n \\
i n\end{array}$ & $\begin{array}{l}\stackrel{0}{i} \\
\text { in }\end{array}$ \\
\hline 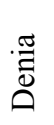 & $\begin{array}{l}\stackrel{\circ}{ } \\
\text { ஸై }\end{array}$ & $\begin{array}{l}\stackrel{0}{0} \\
\infty \\
\dot{y}\end{array}$ & $\begin{array}{l}\stackrel{0}{0} \\
\stackrel{0}{0} \\
1\end{array}$ & $\begin{array}{l}\dot{O}^{\circ} \\
\infty \\
\dot{\infty}\end{array}$ & $\begin{array}{l}\stackrel{0}{+} \\
\dot{v} \\
\stackrel{1}{p}\end{array}$ & $\frac{\stackrel{O}{0}^{\circ}}{\stackrel{i}{7}}$ \\
\hline $\begin{array}{l}\mathscr{E} \\
. \stackrel{0}{E} \\
\sum \\
\sum\end{array}$ & $\begin{array}{l}\stackrel{0}{i} \\
\stackrel{2}{8} \\
\infty\end{array}$ & $\frac{\stackrel{\circ}{N}}{\hat{a}}$ & $\begin{array}{l}\stackrel{0}{0} \\
\stackrel{q}{q}\end{array}$ & $\stackrel{\stackrel{\circ}{i}}{\stackrel{\sim}{n}}$ & $\frac{\stackrel{\circ}{n}}{\stackrel{i}{7}}$ & $\begin{array}{l}\stackrel{0}{0} \\
\stackrel{i}{i}\end{array}$ \\
\hline 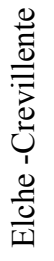 & $\stackrel{\stackrel{\circ}{~}}{\stackrel{0}{~}}$ & $\begin{array}{l}\stackrel{0}{\circ} \\
\stackrel{े}{े}\end{array}$ & 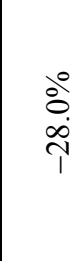 & 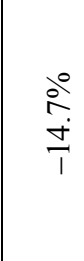 & $\stackrel{\stackrel{\circ}{\circ}}{a}$ & $\begin{array}{l}\delta_{0}^{0} \\
\dot{1} \\
i\end{array}$ \\
\hline
\end{tabular}

In the case of Alzira, in 2014 and 2015 an adjustment had to be made to the financial statements in order to make the comparison possible. The results of previous years that were displayed in equity were reclassified to creditors resulting in negative equity and therefore the ROE became meaningless.

Regarding the IRR results, with the Method 1.a the IRR varies between $-5.93 \%$ obtained in Alzira and 5.38\% of Torrevieja. In Method 1.b the IRR goes from $-5.40 \%$ for Alzira to $10.18 \%$ in Torrevieja. Finally, the results of Method 2 differ, ranging from $3.47 \%$ for Manises to $13.15 \%$ in Elche - Crevillente.

The IRR results vary depending on the methodology used. In general, the best results are obtained using method 2, except in the case of Manises in which the best result is derived using Method 1.b (Figure 2). 


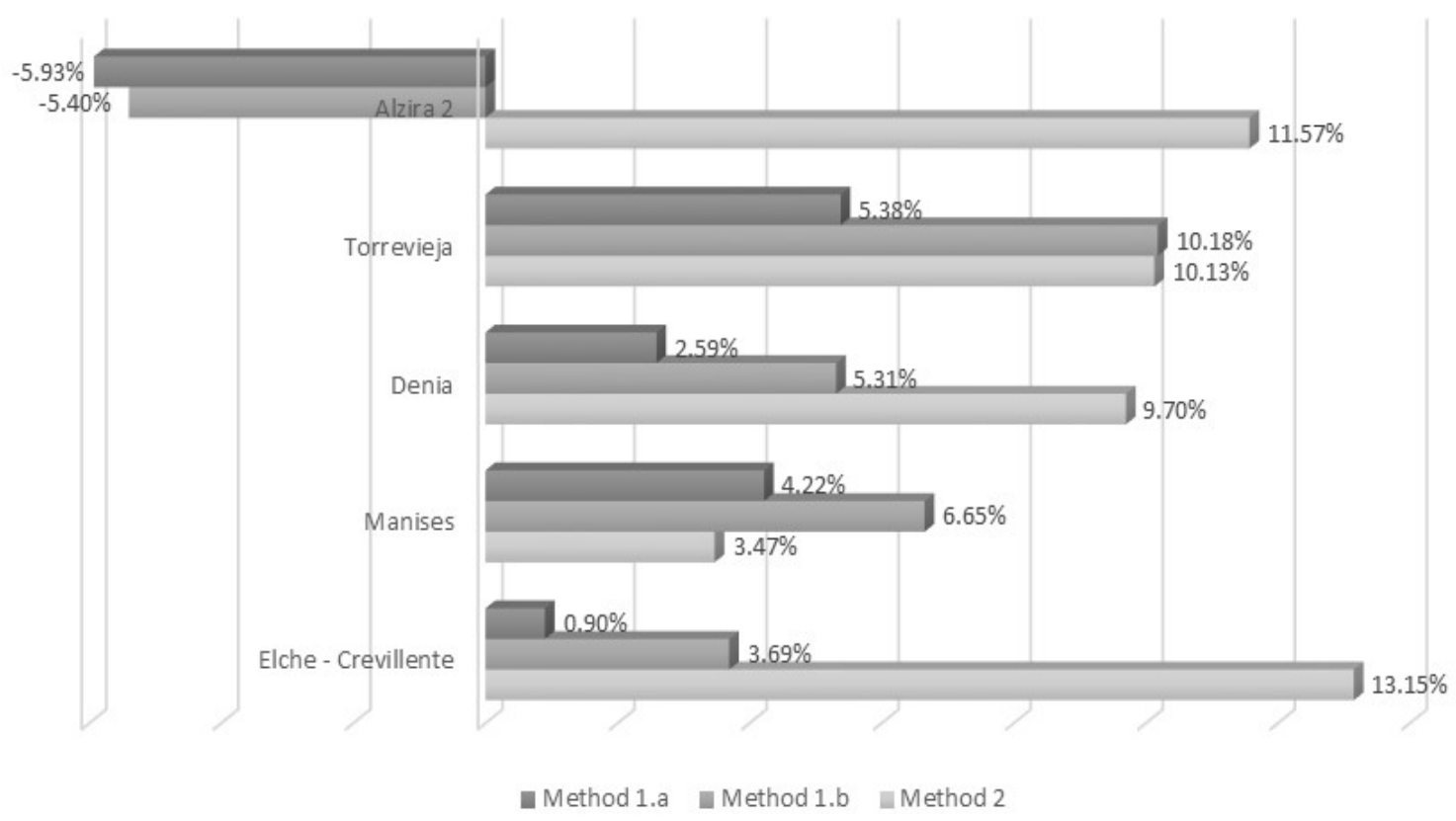

Figure 2. Internal rate of return (source: prepared by authors (2018))

\section{Discussion}

The financial statements of the concessionaire are based on the estimates included in its economicfinancial plan, spread over 15 years (until the end of the contract), and this is updated only in the event of substantial changes in the assumptions used. The return established in the economicfinancial plan is always below $7.5 \%$ (the limitation included in the contract), therefore the annual estimated incomes are adjusted to that plan. This plan is annually reviewed and accepted by the auditing company, so the estimate of the incomes is considered valid from this point of view.

It is difficult to apply these criteria to calculate the IRR and to know the real situation of the collections and payments of a PPP. Given the new accounting standards, it is impossible to know the real IRR, as the concessionaires are estimating the earnings in their accounts.

The main differences between the methods used to calculate the IRR are due to the real accruals of the collections and payments, since the methodology does not follow the accrual accountting basis. In this way, for instance, items such as the salaries of the civil servants that work in the concessions have a positive effect on the annual cash flow, since this is reimbursed to the Administration with long delays. Another example of this is the inter-center movement billing, which can have either a positive or negative effect on the cash flow, depending on the net result between patients referred and patients received.

In addition, the estimation of the future collections and payments is based on hypotheses of the most likely scenario. For this reason, the real and definitive IRR of these contracts cannot be known with certainty until the end of the 15 -year contract. It should further be borne in mind that the different concessions are in different moments of time regarding the expiration date of the contract.

As previously mentioned, the indebtedness ratio is very high in all the concessions and the shareholders appear as creditors to a greater or lesser extent through participative loans. The interest rates of these loans, in most cases, were higher than the cost of the bank financing received, and this could imply an extra retribution to the shareholders.

The new accounting standards for concessional contracts poses a clear obstacle when trying to calculate the real profitability of the concessions. It is very difficult to estimate, for instance, the real collections of every period or try to reconcile the data displayed in the financial statements with the real payments made by the Administration.

If all the required information had been available, the results obtained may have been different. Other authors have also mentioned the 
lack of public information (Acerete, Stafford, \& Stapleton, 2011, pp. 533-549) and questioned the benefits of this system of administrative concessions (Acerete, Gasca, Stafford, \& Stapleton, 2015, pp. 502-518). It should finally be noted that the resulting IRR appears to be quite high considering the low risk of the investment (Vecchi et al., 2010, pp. 125-132; Hovy, 2015, pp. 1-8).

\section{Limitations}

The main limitation of this study is the lack of complete information. As a result, the calculation of the IRR could not be made with the desired accuracy.

In addition, as some of the concessions still have many years remaining until the end of the contract, we were forced to make certain assumptions and the hypotheses used could have a significant influence on the results obtained.

Furthermore, as the concessions started activity in different years, they are therefore not comparable from the point of view of the maturity of the business.

\section{Conclusions}

This paper faces problems in the calculation of the limiting clause on profitability based on accounting definitions, which have been affected by changes in accounting standards. We had to interpret that clause and we went further considering the economic nature of the interests paid to shareholders as distribution of profits. In addition, we developed an "ad hoc" method trying to approach to the financial concept of cash flow. On the other hand, empirical evidence on profitability (ROA and ROE) of this special PPP in health care is provided.

The IRRs obtained with Method 2 are always positive and, in general, exceed the limit of $7.5 \%$ established in the contract. This method calculates profitability using the estimated cash flow for every period, taking into account when the collections and payments occur.

The concession that presents the most important change between the different methods is Alzira that varies from a negative value of more than $5 \%$ to a positive value of $11.57 \%$.

The changes in the accounting standards hinder the comparability of the financial information and it's follow-up.

The new accounting standards for concessionnal contracts means, to a great extent, the use of accounting judgement, as the financial statements depend on the economic-financial plan of the concessionaire. The hypothesis used to formulate that plan are not disclosed, resulting in asymmetric information. The value of the tangible assets (investments made) is unknown, as is how they are amortized, the improvement measures taken or the costs involved in its maintenance. The current financial statements make control of the concession contract by the public administration very difficult.

\section{Acknowledgements}

The authors would like to thank members (Carla Sancho and Carlos Roche) of the Health Department (Conselleria de Sanitat Universal i Salut Pública) of the Valencian Community.

\section{Funding}

This study has received no financing of any kind.

\section{Disclosure Statement}

The authors have no competing financial, professsional, or personal interests from other parties.

\section{References}

Acerete, B., Gasca, M., Stafford, A., \& Stapleton, P. (2015). A comparative policy analysis of healthcare PPPs: Examining evidence from two Spanish regions from an international perspective. Journal of Comparative Policy Analysis: Research and Practice, 17(5), 502518. https://doi.org/10.1080/13876988.2015.1010789

Acerete, B., Stafford, A., \& Stapleton, P. (2011). Spanish healthcare public private partnerships: The „Alzira model“. Critical Perspectives on Accounting, 22(6), 533-549. https://doi.org/10.1016/j.cpa.2011.06.004

Allard, G., \& Trabant, A. (2007). Public-private partnerships in Spain. Lessons and opportunities.

Anderson, S. (2012). Public, private, neither, both? Publicness theory and the analysis of healthcare organisations. Social Science and Medicine, 74(3), 313-322.

https://doi.org/10.1016/j.socscimed.2011.07.021

Barnes, P. (1987). The analysis and use of financial ratios: A review article. Journal of Business Finance and Accounting, 14(4), 449-461. https://doi.org/10.1111/j.1468-5957.1987.tb00106.x

Boletín Oficial del Estado. (2007). Real Decreto 1514/2007, de 16 de noviembre, por el que se aprueba el Plan General de Contabilidad. Retrieved from https://www.boe.es/boe/dias/2007/11/20/pdfs/C00001 -00152.pdf

Boletín Oficial del Estado. (2010). Orden EHA/3362/2010, de 23 de diciembre, por la que se aprueban las normas de adaptación del Plan General de Contabilidad a las empresas concesionarias de infraestructuras públicas. 
Caballer-Tarazona, M., \& Vivas-Consuelo, D. (2016). A cost and performance comparison of Public Private Partnership and public hospitals in Spain. Health Economics Review, 6(1), 17. https://doi.org/10.1186/s13561-016-0095-5

Hamilton, G., Kachkynbaeva, M., \& Wachsmuth, I. (2012, October). A preliminary reflection on the best practice in PPP in healthcare sector: A review of different PPP case studies and experiences. In Conference of PPPs in Health Manila 2012: Developing Models, Ensuring Sustainability: Perspectives from Asia and Europe.

Hellowell, M., \& Pollock, A. M. (2009). The private financing of NHS hospitals: Politics, policy and practice. Economic Affairs, 29(1), 13-19. https://doi.org/10.1111/j.1468-0270.2009.01861.x

Hoppe, E. I., Kusterer, D. J., \& Schmitz, P. W. (2013). Public-private partnerships versus traditional procurement: An experimental investigation. Journal of Economic Behavior and Organization, 89, 145-166. https://doi.org/10.1016/j.jebo.2011.05.001

Hovy, P. (2015). Risk allocation in public-private partnerships: Maximizing value for money, International Institute for Sustainable Development, 18. Retrieved from https://www.iisd.org/sites/default/ files/publications/risk-allocation-ppp-maximizingvalue-for-money-discussion-paper.pdf

Jamali, D. (2004). Success and failure mechanisms of public private partnerships (PPPs) in developing countries. International Journal of Public Sector Management, 17(5), 414-430. https://doi.org/10.1108/09513550410546598

Kwak, Y. H., Chih, Y., \& Ibbs, C. W. (2009). Towards a comprehensive understanding of public private partnerships for infrastructure development. California Management Review, 51(2), 51-78. https://doi.org/10.2307/41166480

Lev, B. (1974). Financial statement analysis. A new approach. Prentice-Hall. Eglewood Hills, NJ.

Lev, B., \& Sunder, S. 1979. Methodological issues in the use of financial ratios. Journal of Accounting and Economics, 1(3), 187-210. https://doi.org/10.1016/0165-4101(79)90007-7
Megha, C. M., \& Panneer, S. (2017). Public private partnership: A developing trend in the health care sector in India. Journal of Social Work Education and Practice, 2(1), 17-24.

Mudyarabikwa, O., Tobi, P., \& Regmi, K. (2017). Publicprivate partnerships to improve primary healthcare surgeries: Clarifying assumptions about the role of private provider activities. Primary Health Care Research and Development, 18(4), 366-375. https://doi.org/10.1017/S1463423617000147

Roehrich, J. K., Lewis, M. A., \& George, G. (2014). Are public-private partnerships a healthy option? A systematic literature review. Social Science and Medicine, 113, 110-119. https://doi.org/10.1016/j.socscimed.2014.03.037

Singh, A., \& Prakash, G. (2010). Public-private partnerships in health services delivery. Public Management Review, 12(6), 829-856. https://doi.org/10.1080/14719037.2010.488860

Torchia, M., \& Calabrò, A. (2015). Public-private partnerships in the health care sector: A systematic review of the literature. Public Management Review, 17(2), 37-41. https://doi.org/10.1080/14719037.2013.792380

Vecchi, V., Hellowell, M., \& Longo, F. (2010). Are Italian healthcare organizations paying too much for their public-private partnerships?, Public Money and Management, 30(2), 125-132. https://doi.org/10.1080/09540961003665586

Wang, H., Xiong, W., Wu, G., \& Zhu, D. (2017). Publicprivate partnership in Public Administration discipline: a literature review. Public Management Review, 20(2), 293-316. https://doi.org/10.1080/14719037.2017.1313445

Whittington, G. (1980). Some basic properties of accounting ratios. Journal of Business Finance \& Accounting, 7(2), 219-232. https://doi.org/10.1111/j.1468-5957.1980.tb00738.x

World Bank Institute. (2012). Public-private partnerships Reference guide version 1.0. International Bank for Reconstruction and Development / International Development Association or The World Bank Washington, D.C., USA., 230. 